\title{
Molecular and Biological Characterization of Hammondia heydorni-Like Oocysts From a Dog Fed Hearts From Naturally Infected White-Tailed Deer (Odocoileus virginianus)
}

\author{
Author(s): J. P. Dubey , C. Sreekumar , K. B. Miska , D. E. Hill , M. C B. Vianna , and D. S. Lindsay \\ Source: Journal of Parasitology, 90(5):1174-1176. 2004. \\ Published By: American Society of Parasitologists \\ DOI: http://dx.doi.org/10.1645/GE-324R \\ URL: http://www.bioone.org/doi/full/10.1645/GE-324R
}

BioOne (www.bioone.org) is a nonprofit, online aggregation of core research in the biological, ecological, and environmental sciences. BioOne provides a sustainable online platform for over 170 journals and books published by nonprofit societies, associations, museums, institutions, and presses.

Your use of this PDF, the BioOne Web site, and all posted and associated content indicates your acceptance of BioOne's Terms of Use, available at www.bioone.org/page/terms of use.

Usage of BioOne content is strictly limited to personal, educational, and non-commercial use. Commercial inquiries or rights and permissions requests should be directed to the individual publisher as copyright holder. 
Genotypic analysis of Toxoplasma gondii isolates from pigs. Journal of Parasitology 84: 639-641.

Owen, M. R., AND A. J. Trees. 1999. Genotyping of Toxoplasma gondii associated with abortion in sheep. Journal of Parasitology 85: 382_ 384.

Poelma, F. G., AND P. Zwart. 1972. Toxoplasmose bij kroonduiven en andere vogels in de Koninklijke Rotterdamse Diergaarde 〈Blijdorp〉. Acta Zoologica et Pathologica Antverpiensia 55: 29-40.

Sreekumar, C., J. R. RaO, A. K. Mishra, D. Ray, G. C. Bansal.
(2003). In vitro generation of cloned populations of Toxoplasma gondii. Parasitology Research 90: 489-492.

Tenter, A. M., A. R. Heckeroth, And L. M. Weiss. 2000. Toxoplasma gondii: From animals to humans. International Journal for Parasitology 30: 1217-1258.

Walton, B. C., AND K. W. WaLLs. 1964. Prevalence of toxoplasmosis in wild animals from Fort Stewart, Georgia, as indicated by serological tests and mouse inoculation. American Journal of Tropical Medicine and Hygiene 13: 530-533.

\section{Molecular and Biological Characterization of Hammondia heydorni-Like Oocysts From a Dog Fed Hearts From Naturally Infected White-Tailed Deer (Odocoileus virginianus)}

J. P. Dubey, C. Sreekumar, K. B. Miska, D. E. Hill, M. C. B. Vianna, and D. S. Lindsay*, Animal Parasitic Diseases Laboratory, Animal and Natural Resources Institute, Agricultural Research Service, United States Department of Agriculture, Beltsville, Maryland 20705; ${ }^{*}$ Center for Molecular Medicine and Infectious Diseases, Department of Biomedical Sciences and Pathobiology, Virginia-Maryland Regional College of Veterinary Medicine, Virginia Tech, 1410 Prices Fork Road, Blacksburg, Virginia 24061. e-mail: jdubey@anri.barc.usda.gov

ABSTRACT: Neospora caninum and Hammondia heydorni are morphologically and phylogenetically related coccidians that are found in dogs. Although there is serological evidence of $N$. caninum infection in the white-tailed deer (Odocoileus virginianus), the parasite has not been yet isolated from the tissues of this host. In an attempt to isolate $N$. caninum from deer, hearts from 4 deer with antibodies to N. caninum were fed to 2 dogs. One of these dogs shed unsporulated oocysts $12-14 \mu \mathrm{m}$ in diameter. Sporulated oocysts were not infective to Mongolian gerbils (Meriones ungulatus), and DNA isolated from these oocysts was not amplified using $N$. caninum-specific primers. However, positive amplification with the $H$. heydorni-specific first internal transcribed spacer (ITS-1) primers and common toxoplasmatiid ITS-1 primers confirmed the presence of $H$. heydorni DNA in the samples. The oocysts were considered to be $H$. heydorni on the basis of their morphology, biology, and molecular characteristics. This is the first record of a H. heydornilike parasite in the white-tailed deer.

Neospora caninum is a parasite of livestock and companion animals and is an important cause of bovine abortion in dairy cattle worldwide (Dubey, 2003). It is transmitted transplacentally, by the ingestion of infected tissues and by the ingestion of food and water contaminated with oocysts excreted in the feces of dogs. The domestic dog is the only known definitive host for $N$. caninum (McAllister et al., 1998). The role of the dog in the epidemiology of $N$. caninum is currently unclear because experimentally infected dogs usually excrete only a few oocysts, and the parasite has been isolated only a few times from naturally infected dogs (Basso et al., 2001; Gondim et al., 2002; Šlapeta, Modry et al., 2002; McGarry et al., 2003). Furthermore, $N$. caninum oocysts morphologically resemble the oocysts of a related coccidian, Hammondia heydorni, and there is no simple method to distinguish them.

Little is known about the life cycle of $H$. heydorni or whether additional Hammondia species that use dogs as their definitive host occur (Dubey et al., 2002; Schares et al., 2002; Šlapeta, Modry et al., 2002). Hammondia heydorni-like oocysts were found in the feces of dogs that were fed naturally infected tissues from cattle (Bos taurus), water buffalo (Bubalus bubalis), sheep (Ovis aries), goats (Capra hircus), moose (Alces alces), and camels (Camelus dromedarius) (reviewed in Dubey et al., 2002). In addition, red foxes (Vulpes vulpes) fed tissues from sheep, cattle, roe deer (Capreolus capreolus), mountain gazelle (Gazella gazella), and reindeer (Rangifer tarandus) shed $\mathrm{H}$. heydorni-like oocysts in their feces (Dubey et al., 2002). Until recently, all these oocysts excreted in feces of dogs and foxes were considered 1 species. However studies of Schares et al. $(2002,2003)$ indicated the parasite in foxes is different morphologically and biologically from the parasite in dog feces. Furthermore, molecular studies indicate that there are more than 1 genetic variant at present designated as $H$. heydorni (Sreekumar et al.,
2003). We report isolation of another $H$. heydorni-like parasite from the white-tailed deer (Odocoileus virginianus) for the first time from this host.

During studies on the genetic characterization of Toxoplasma gondii isolates from wildlife (Dubey et al., 2004) in March 2003, tissues from 4 white-tailed deer from Mississippi were also examined for antibodies to $N$. caninum using the $N$. caninum-agglutination test (NAT; Romand et al., 1998). The NAT titers were $1: 25$ in 2 and 1:50 in 2 deer. Heart tissue from these 4 deer were pooled and fed to 2 laboratory-raised dogs. The dogs had not ingested uncooked meat products before feeding on deer tissues. Feces of these dogs were examined daily for $3 \mathrm{wk}$ for coccidian oocysts by floatation in sugar solution. Oocysts were collected from feces, sporulated in $2.5 \%$ potassium dichromate aqueous solution at room temperature for 7 days, and then stored at $4 \mathrm{C}$ until used. Sporulated oocysts were washed with water to remove potassium dichromate by centrifugation, treated with $5.25 \%$ sodium hypochlorite solution (Clorox), washed, and divided into aliquots for bioassay, in vitro cultivation, and polymerase chain reaction (PCR) studies. Aliquots were fed to 2 gerbils (Meriones ungulatus) and to 5 interferon gamma gene knockout (KO) mice (Dubey and Lindsay, 1998). For in vitro cultivation, 1 aliquot was vortexed for 5 min with $500-\mu \mathrm{m}$ glass beads (Microbeads, Ferro Corporation, Cleveland, Ohio) and subsequent incubation in an excystation medium (sodium taurocholate $250 \mathrm{mg}$, sodium deoxycholic acid $400 \mathrm{mg}$, trypsin [1:250] $25 \mathrm{mg}$ in $100 \mathrm{ml}$ saline, $\mathrm{pH} 7.5$ ) at $37 \mathrm{C}$. After excystation, the suspension was washed with growth medium and layered over each of the $2 \mathrm{CV} 1$ (African Green monkey [Cercopithecus aethiops] kidney cells) and equine dermal cell monolayers grown over coverslips in multiwell plates. The coverslips were removed at intervals, fixed with Bouin fixative and stained with Giemsa.

For obtaining DNA, the oocyst suspension was ruptured by 2-3 freeze-thaw cycles, followed by grinding of the pellet in small volumes (about $30 \mu \mathrm{l}$ ) in a $0.2-\mathrm{ml}$ microtissue grinder (Wheaton, Fischer Scientific, Pittsburgh, Pennsylvania). The DNA was extracted from the homogenized suspensions using DNAzol (MRC, Cincinnati, Ohio) according to the manufacturer's instructions. Five sets of primers, Neospora-specific NP6/NP21 (Yamage et al., 1996), H. heydorni-specific first internal transcribed spacer (ITS-1) RAPD primers JS4/JS5 (Šlapeta, Koudela et al., 2002), H. heydorni-specific HhAP7 and HhAP10 primers, and common toxoplasmatiid ITS-1 primers CT1/CT2 (Sreekumar et al., 2003), were used for PCR amplification of the DNA, according to previously described protocols. The PCR products were electrophoresed in a $2 \%$ agarose gel, and the gel-cleaned PCR products were directly sequenced in both directions using the Big Dye terminator system, version 3.1 (Applied Biosystems, Foster City, California) using an ABI 377 sequencer. The sequence chromatograms were edited using Sequencher 4.1 software (Genecodes Corp., Ann Arbor, Michigan). 

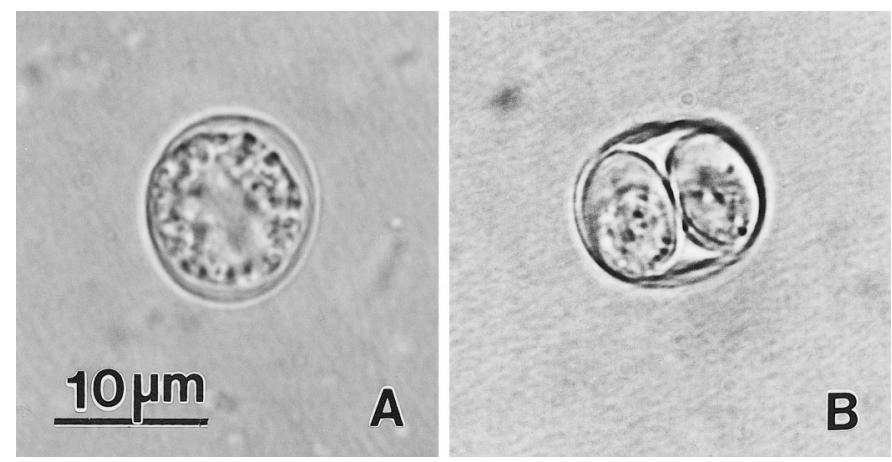

FIGURE 1. Unsporulated (A) and sporulated (B) oocysts of the Hammondia heydorni-like parasite shed in the feces of a dog fed naturally infected deer tissues.

Searches were performed using BLAST (http://www.ncbi.nlm.nih.gov/ BLAST/) to determine whether the sequences were similar to any of the previously published sequences.

One dog shed unsporulated oocysts in feces 10-12 days after ingesting deer tissue. Unsporulated oocysts were 12-14 $\times 10-12 \mu \mathrm{m}(\mathrm{n}$ $=100$ ) in size, and sporulated oocysts contained 2 sporocysts, $6-8 \times$ 4-6 $\mu \mathrm{m}$ in size (Fig. 1A, B). There were 4 sporozoites in each sporocyst. The gerbils and $\mathrm{KO}$ mice fed sporocysts remained asymptomatic, and antibodies to $N$. caninum were not found in 1:25 dilution of their serum tested 30 days after inoculation. Protozoans were not found in histological sections of rodents fed oocysts.

Sporozoites were found to excyst within $20 \mathrm{~min}$ of incubation of cleaned oocysts in the excystation media. The sporozoites did not infect the equine dermal cell monolayer. Dividing forms could be seen in the CV1 cells stained on day 14 after inoculation. However, no additional growth was seen, and the parasites gradually disappeared from the monolayers after $4 \mathrm{wk}$. A $H$. heydomi-like parasite from the feces of a dog was grown in vitro by Speer et al. (1988), but they were unable to infect new monolayers by passaging, and the parasite died out in culture. Schares et al. (2003) maintained a H. hedorni-like parasite from the feces of foxes in vitro and were able to demonstrate oocyst shedding in fox by feeding the infected culture. However, the parasite that Schares et al. (2003) studied was different from the parasite from dogs; its oocysts were larger and it was not transmissible to dogs through tissues of an intermediate host (sheep). In the present study, only a few oocysts were shed in dog feces, and we were unable to obtain sustainable growth in culture.

No amplification was observed with either the $N$. caninum-specific primers or the $H$. heydorni-specific RAPD-derived primers. The $H$. heydorni-specific ITS-1 primers resulted in the amplification of a product of the expected size $(\sim 270 \mathrm{bp})$. The sequences (GenBank AY531300) were found to be identical to those of $H$. heydorni isolates from dogs and fox. The common toxoplasmatiid ITS-1 primers resulted in the amplification of a product in the size range of $399 \mathrm{bp}$ (GenBank
AY530018). The results of the BLAST search of this fragment with the public database are shown in Table I. Polymorphism was noticed at 8 locations. The sequences of the deer isolate were identical to that of a $H$. heydorni isolate of dog from the United States. However, the sequences also had greater similarity to an isolate from fox than other canine isolates from Germany, Czech Republic, and Australia. Recent evidence has pointed to the presence of molecular differences among $H$. heydorni isolates from dogs and foxes. Mohammed et al. (2003) concluded that the isolates of $H$. heydorni from foxes and dogs constitute genetically different populations on the basis of the ribosomal DNA sequences. The deer isolate, which was excreted by a dog, was found to be closer to the fox isolate than the dog isolates from Germany, Czech Republic, and Australia.

The results of the present study indicate that dogs can excrete $H$. heydorni-like oocysts in their feces, and these must be distinguished from $N$. caninum oocysts. The results also point to a greater genetic diversity among the $H$. heydorni isolates irrespective of their host.

\section{LITERATURE CITED}

Basso, W., L. Venturini, M. C. Venturini, D. E. Hill, O. C. H. Kwok, S. K. Shen, AND J. P. Dubey. 2001. First isolation of Neospora caninum from the feces of a naturally infected dog. Journal of Parasitology 87: 612-618.

Dubey, J. P. 2003. Neosporosis in cattle. Journal of Parasitology 89(Suppl.): S42-S46.

- AND D. S. LINDSAY. 1998. Isolation in immunodeficient mice of Sarcocystis neurona from opossum (Didelphis virginiana) faeces, and its differentiation from Sarcocystis falcatula. International Journal for Parasitology 28: 1823-1828.

, B. C. Barr, J. R. Barta, I. Bjerkas, C. Bjorkman, B. L. Blagburn, D. D. Bowman, D. Buxton, J. T. Ellis, B. GotTstein, A. Hemphill, D. E. Hill, D. K. Howe, M. C. Jenkins, Y. Kobayashi, B. Koudela, A. E. Marsh, J. G. Mattsson, M. M. McAllister, D. Modry, Y. Omata, C. A. Speer, A. J. Trees, A. Uggla, S. J. Upton, D J. L. Williams, And D. S. Lindsay. 2002. Redescription of Neospora caninum and its differentiation from related coccidia. International Journal for Parasitology 32: 929-946.

, D. H. Graham, R. W. de Young, E. Dahl, M. L. Eberhard, E. K. Nace, K. Won, H. Bishop, G. Punkosdy, C. Sreekumar, M. C. B. Vianna, S. K. Shen, O. C. H. Kwok, J. A. Sumners, S. Demarais, J. G. Humphreys, and T. Lehmann. 2004. Molecular and biologic characteristics of isolates of Toxoplasma gondii from wildlife in the United States. Journal of Parasitology 90: 67-72.

GondiM, L. F. P., L. GAO, AND M. M. McAllister. 2002. Improved production of Neospora caninum oocysts, cyclical oral transmission between dogs and cattle, and in vitro isolation from oocysts. Journal of Parasitology 88: 1159-1163.

McAllister, M. M., J. P. Dubey, D. S. Lindsay, W. R. Jolley, R. A. Wills, AND A. M. McGuire. 1998. Dogs are definitive hosts of Neospora caninum. International Journal for Parasitology 28: 1473-1478.

McGarry, J. W., C. M. Stockton, D. J. L. Williams, and A. J. Trees.

TABLE I. Sequence comparison of a 399-bp region of ITS-1 from different isolates of Hammondia heydorni.

\begin{tabular}{|c|c|c|c|c|c|c|c|c|c|}
\hline \multirow{2}{*}{$\begin{array}{c}\text { Isolate } \\
\text { location/host(s) }\end{array}$} & \multirow{2}{*}{$\begin{array}{c}\text { GenBank } \\
\text { accession no. }\end{array}$} & \multicolumn{8}{|c|}{ Polymorphic sites } \\
\hline & & 165 & 209 & 293 & 317 & 331 & 356 & 361 & 368 \\
\hline United States/Deer, dog* & AY530018* & A & $\mathrm{C}$ & A & $\mathrm{T}$ & $\mathrm{C}$ & $\mathrm{C}$ & $\mathrm{T}$ & $-\dagger$ \\
\hline USA?/Dog & AF096501 &.+ & . & . & . & . & . & . & - \\
\hline Germany/goat, fox & AF395867 & . & G & . & . & . & . & . & - \\
\hline Czech Republic/Dog & AF317282 & G & G & G & $\mathrm{C}$ & . & A & . & $\mathrm{T}$ \\
\hline Germany/Guinea pig, dog & AY189897 & G & G & G & $\mathrm{C}$ & $\mathrm{T}$ & A & . & - \\
\hline Australia/Dog & AF508030 & G & G & G & $\mathrm{C}$ & $\mathrm{T}$ & A & . & - \\
\hline Czech Republic/Dog & AF317281 & $\mathrm{G}$ & $\mathrm{G}$ & $\mathrm{G}$ & $\mathrm{C}$ & $\mathrm{T}$ & $A$ & $\mathrm{C}$ & $\mathrm{T}$ \\
\hline
\end{tabular}

* Present study.

$\dagger$ Alignment gaps are indicated by dashes.

$\ddagger$ Sequences identical to the deer isolate are indicated with a period. 
2003. Protracted shedding of oocysts of Neospora caninum by a naturally infected foxhound. Journal of Parasitology 89: 628-630.

Mohammed, O. B., A. J. Davies, H. S. Hussein, P. Daszak, and J. T. ELLIS. 2003. Hammondia heydorni from the Arabian mountain gazelle and red fox in Saudi Arabia. Journal of Parasitology 89: 535539.

Romand, S., P. Thulliez, And J. P. Dubey. 1998. Direct agglutination test for serologic diagnosis of Neospora caninum infection. Parasitology Research 84: 50-53.

Schares, G., A. O. Heydorn, A. C. H. Mehlhorn, L. Geue, M. Peters, AND F. J. ConRaths. 2002. In contrast to dogs, red foxes (Vulpes vulpes) did not shed Neospora caninum upon feeding of intermediate host tissues. Parasitology Research 88: 44-52.

- J. Meyer, A. Bärwald, F. J. Conraths, R. Riebe, W. Bohne, K. Rohn, AND M. Peters. 2003. A Hammondia-like parasite from the European fox (Vulpes vulpes) forms biologically viable tissue cysts in cell culture. International Journal for Parasitology 33: 229-234.

Šlapeta, J. R., B. Koudela, J. Votypka, D. Modry, R. Horejs, And J. LUKES. 2002. Coprodiagnosis of Hammondia heydorni in dogs by PCR based amplification of ITS 1 rRNA: Differentiation from morphologically indistinguishable oocysts of Neospora caninum. The Veterinary Journal 163: 147-154.

, D. Modry, I. Kyselova, R. Horejs, J. Lukes, and B. KouDELA. 2002. Dog shedding oocysts of Neospora caninum: PCR diagnosis and molecular phylogenetic approach. Veterinary Parasitology 109: 157-167.

Speer, C. A., J. P. Dubey, J. A. Blixt, and B. L. Blagburn. 1988. Development of Hammondia heydorni in cultured bovine and ovine cells. Journal of Protozoology 35: 352-356.

Sreekumar, C., D. E. Hill, V. M. Fournet, B. M. Rosenthal, D. S Lindsay, And J. P. Dubey. 2003. Detection of Hammondia heydorni-like organisms and their differentiation from Neospora caninum using random-amplified polymorphic DNA-polymerase chain reaction. Journal of Parasitology 89: 1082-1085.

Yamage, M., O. Flechtner, And B. Gottstein. 1996. Neospora caninum: Specific oligonucleotide primers for the detection of brain "cyst" DNA of experimentally infected nude mice by the polymerase chain reaction (PCR). Journal of Parasitology 28: 1473-1478.

\title{
Ingestion of Cryptosporidium Oocysts by Caenorhabditis elegans
}

\author{
Obed Huamanchay, Linda Genzlinger, Miguel Iglesias, and Ynes R. Ortega*, Center for Food Safety and Department of Food Science and \\ Technology, University of Georgia, 1109 Experiment Street, Griffin, Georgia 30223; *To whom correspondence should be addressed. e-mail: \\ ortega@griffin.uga.edu
}

ABSTRACT: Cryptosporidium parvum has been associated with outbreaks of human illness by consumption of contaminated water, fresh fruits, and vegetables. Free-living nematodes may play a role in pathogen transmission in the environment. Caenorhabditis elegans is a freeliving soil nematode that has been extensively studied and serves as a good model to study possible transmission of $C$. parvum oocysts that may come into contact with produce before harvest. The objective of this study was to determine whether $C$. elegans could serve as a potential mechanical vector for transport of infectious $C$. parvum and $C y$ clospora cayetanensis in agricultural settings and whether C. elegans could ingest, excrete, and protect oocysts from desiccation. Seventy to $85 \%$ of worms ingested between 0 and 500 oocysts after 1 and $2 \mathrm{hr}$ incubation with oocysts. Most of the nematodes ingested between 101 and 200 oocysts after 2 hr. Intact oocysts and empty shells were excreted by nematodes. Infectivity was determined by the neonatal assay with different treatments of worms (intact or homogenized) or oocysts or both. Adult $C$. elegans containing $C$. parvum kept in water were infective for mice. In conclusion, $C$. elegans adults can ingest and excrete C. parvum oocysts. Caenorhabditis elegans containing C. parvum oocysts can infect mice but does not seem to protect oocysts from extreme desiccation at $23 \mathrm{C}$ incubation of a day or longer. Cyclospora oocysts were not ingested by $C$. elegans. The role of free-living nematodes in produce contamination needs to be further examined.

Parasites, such as Cryptosporidium parvum, Cyclospora cayetanensis, and Giardia lamblia have been causative agents in outbreaks of human illness associated with consumption of contaminated water, fresh fruits, and vegetables (Orlandi et al., 2002).

The dissemination of pathogenic parasites onto raw produce has not been thoroughly studied (Wasilewska and Webster, 1975) but may be introduced during pre- and postharvest practices. Potential agricultura sources of produce contamination include farm workers, animals, irrigation water, soil, and insects. Flies have been shown to transport infectious $C$. parvum oocysts (Graczyk et al., 1999). If produce comes into contact with manure, then free-living soil nematode contamination could occur. Irrigation water can also be contaminated with feces of humans and wild animals, introducing large numbers of parasites into the environment, particularly in rivers and lakes. Rotifers can ingest $C$. parvum oocysts and $G$. lamblia cysts. The fate of the parasites once ingested by rotifers needs to be studied further (Fayer et al., 2000; Trout et al., 2002).

A well-studied and harmless free-living nematode, Caenorhabditis elegans, may serve as a model to study nematodes acting as carriers or transport hosts by ingesting harmful bacteria and then protecting such organisms from environmental conditions while in the gut (Chang et al., 1960). Salmonella enterica serotype Poona and S. typhimurium can be ingested by $C$. elegans, providing protection against inactivation by produce sanitizers (Labrousse et al., 2000; Caldwell et al., 2003). The objective of the present study was to determine whether C. elegans could serve as a potential mechanical vector for transport of infectious Cryptosporidium in agricultural settings and if the nematode could ingest, excrete, and protect oocysts from desiccation. Caenorhabditis elegans (N2, wild-type strain) was used in all experiments. The worms were grown on K-agar plates ( $\mathrm{pH}$ 6.5) (2.36 g potassium chloride, $3 \mathrm{~g}$ sodium chloride, $2.5 \mathrm{~g}$ Bacto Peptone, and $17 \mathrm{~g} / \mathrm{L}$ agar in deionized water). The agar was autoclaved, cooled, and supplemented with $1 \mathrm{~g}$ cholesterol (95\%), $11.1 \mathrm{~g}$ calcium chloride, and $24.7 \mathrm{~g}$ magnesium sulfate. Medium was distributed in plastic petri plates. Escherichia coli was cultured in OP50 broth (5 g sodium chloride and $10 \mathrm{~g}$ Bacto Peptone) for $24 \mathrm{hr}$, plated in $\mathrm{K}$ agar, and incubated at $37 \mathrm{C}$ for $24 \mathrm{hr}$ until confluent growth was established. Nematode cultures were fed with confluent cultures of $E$. coli OP50.

Cryptosporidium parvum oocysts (Iowa isolate, bovine genotype) were obtained from the Parasitology Laboratory, University of Arizona. Oocysts were labeled with Merifluor ${ }^{\circledR}$ Cryptosporidium/Giardia Direct Immunofluorescent Detection Reagent (Meridian Bioscience Inc., Cincinnati, Ohio). The oocysts (approximately $3 \times 10^{7}$ ) were resuspended in $100 \mu \mathrm{K} \mathrm{K}$-medium and $40 \mu \mathrm{l}$ of the Detection Reagent was added. Incubation was at room temperature for $60 \mathrm{~min}$, with mixing every 15 min. Detection Reagent was removed by microcentrifugation $(8,000$ rpm for $4 \mathrm{~min}$ ) and oocysts were washed with fresh K-medium.

Unsporulated $C$. cayetanensis oocysts were obtained from naturally infected individuals with cyclosporiasis. Fecal samples containing oocysts were concentrated using the modified ethyl acetate method followed by a discontinuous sucrose gradient (Ortega et al., 1998).

Between 100 and 200 adult nematodes were placed on K-agar plates 